\title{
Fraude contable y corrupción. Reflexiones en torno a la responsabilidad civil del auditor de estados financieros
}

\author{
Accounting fraud and corruption. Reflections on civil liability \\ of the auditor of financial statements \\ Fraude contábil e corrupção. Reflexões sobre a responsabilidade \\ civil do auditor das demonstrações financeiras
}

\author{
Bruno Ariel Rezzoagli \\ Facultad de Ciencias Económicas, \\ Universidad Nacional del Litoral, Argentina \\ brezzoagli@fce.unl.edu.ar
}

Fecha de recepción: 29/12/2020 Fecha de aceptación: 01/04/2021

\section{Resumen}

Este escrito tiene por objetivo, por un lado, delimitar los elementos distintivos de la corrupción organizacional desde una perspectiva contable, a partir del análisis y caracterización de las prácticas fraudulentas y creativas, y por otro, reflexionar sobre el rol actual del auditor de estados financieros y su responsabilidad frente a la falta de detección de estas. Se trata de un trabajo de metodología cualitativa, de carácter descriptivo y analítico, mediante el empleo de técnicas de investigación documental, con especial análisis de fuentes bibliográficas y de la norma internacional de auditoría (NIA) 240. Con base en dicho estudio, se presenta una serie de conceptos (discrecionalidad, arbitrariedad y elusión contable) que posibilitan una mejor comprensión de las prácticas de contabilidad relacionadas con la corrupción. Asimismo, se exponen las limitaciones de la auditoría financiera en la identificación del fraude contable y se destaca la importancia de una adecuada planificación del trabajo de auditoría. Finalmente, se concluye que el hecho de que las normas contables presenten

Palabras clave - creatividad contable

- fraude

- corrupción

- responsabilidad

- auditoría ambigüedades u otorguen cierto grado de maniobra a quienes preparan la información financiera, y que ello dificulte al auditor identificar prácticas fraudulentas, creativas o elusivas; no lo exime de responsabilidad por los daños y perjuicios patrimoniales que su falta de detección, por mal desempeño, cause en terceros. 
Keywords

- accounting creativity

- fraud

- corruption

- responsibility

- audit

\begin{abstract}
On the one hand, this article aims to delimit the distinctive elements of organizational corruption from an accounting perspective, based on the analysis and characterization of fraudulent and creative practices. On the other hand, it aims to reflect on the current role of the auditor of financial statements and their responsibility in the absence of the detection of such practices. This is a qualitative, descriptive and analytical methodology work, through the use of documentary research techniques, with special analysis of bibliographic sources and the international auditing standard (ISA) 240. Based on this study, a series of concepts (discretion, arbitrariness and accounting avoidance) that allow a better understanding of accounting practices related to corruption are presented. Likewise, the limitations of financial auditing in the identification of accounting fraud are exposed and the importance of an adequate planning of the audit work is highlighted. Finally, it is concluded that the fact that the accounting standards present ambiguities or grant a certain degree of maneuver to those who prepare the financial information, and that this makes it difficult for the auditor to identify fraudulent, creative or elusive practices, does not exempt the auditor from responsibility for the patrimonial damages that not detecting such practices, due to poor performance, causes in third parties.
\end{abstract}

\section{Resumo}

Este artigo tem como objetivo, por um lado, delimitar os elementos distintivos da corrupção organizacional do ponto de vista contábil, com base na análise e caracterização de práticas fraudulentas e criativas, e, por outro, refletir sobre o papel atual do auditor de demonstrações financeiras e sua responsabilidade caso tais práticas não forem detectadas. Trata-se de um trabalho de metodologia qualitativa, descritiva e analítica, através da utilização de técnicas de pesquisa documental, com especial análise de fontes bibliográficas e da norma internacional de auditoria (NIA) 240. Com base neste estudo, é apresentada uma série de conceitos (discricionariedade, arbitrariedade e elusão contábil) que permitem um melhor entendimento das práticas contábeis relacionadas à corrupção. Da mesma forma, são expostas as limitações da auditoria financeira na identificação de fraudes contábeis e é destacada a importância de um planejamento adequado dos trabalhos de auditoria. Por fim, conclui-se que 0 fato de as normas contábeis apresentarem ambiguidades ou concederem certo grau de manobra ao encarregado de elaborar a informação financeira, pode tornar difícil ao auditor a identificação de práticas fraudulentas, criativas ou elusivas, mas não 0 exime de responsabilidade pelos danos e prejuízos patrimoniais que a sua falta de detecção, devido ao mau desempenho, possa gerar a terceiros. 